\title{
Getting ready for REDD+ in Tanzania: a case study of progress and challenges
}

\author{
Neil D. Burgess, Bruno Bahane, Tim Clairs, Finn Danielsen, Søren \\ Dals ga ard, Mikkel Funder, Niklas Hagelberg, Paul Har is on \\ Christognus Haule, Kekilia Kabalimu, Felician Kilahama, Edward \\ Kilawe, Simon L. Lewis, Jon C. Lovett, Gertrude Lyatuu, Andrew R. \\ Marshall, Charles Meshack, Lera Miles, Simon A. H. Milledge, Pantaleo \\ K. T. Munishi, Evarist Nashanda, Deo Shirima, Ruth D. Swetham, Simon \\ WILLCOCK, ANDREW WILLIAMS and ELIAKIM ZAHABU
}

\begin{abstract}
The proposed mechanism for Reducing Emissions from Deforestation and Degradation (REDD+) offers significant potential for conserving forests to reduce negative impacts of climate change. Tanzania is one of nine pilot countries for the United Nations REDD Programme, receives significant funding from the Norwegian, Finnish and German governments and is a participant in the World Bank's Forest Carbon Partnership Facility. In combination, these interventions aim to mitigate green-
\end{abstract}

NeIL D. Burgess (Corresponding author) Department of Biology, University of Copenhagen, Universitetsparken 15, DK-2100, Copenhagen, Denmark, WWF-US, Washington, DC, USA, and UNEP-World Conservation Monitoring Centre, Cambridge, UK. E-mail ndburgess@bio.ku.dk

Bruno Bahane, Christognus Haule, Kekilia Kabalimu, Felician Kilahama and Evarist Nashanda Forestry and Beekeeping Division, Dar es Salaam, Tanzania

Tim Clairs UN-REDD Secretariat, Environment and Energy Group, Bureau for Development Policy, UNDP, New York, USA

Finn Danielsen and Mikkel Funder NORDECO, Copenhagen, Denmark

Søren Dalsgaard and Edward Kilawe Food and Agriculture Organization, Dar es Salaam, Tanzania

Niklas Hagelberg Freshwater \& Terrestrial Ecosystems Branch/DEPI, UNEP, Nairobi, Kenya

Paul Harrison and Andrew Williams Kilimanyika, Arusha, Tanzania

Simon L. LewiS and Simon Willcock Ecology and Global Change Cluster, School of Geography, University of Leeds, Leeds, UK

Jon C. Lovett CSTM-Twente Centre for Studies in Technology and Sustainable Development, University of Twente, Enschede, The Netherlands

Gertrude Lyatuu UNDP Tanzania, Dar es Salaam, Tanzania

ANDREw R. Marshall Environment Department, University of York, York, UK

Charles Meshack Tanzania Forest Conservation Group, Dar es Salaam, Tanzania

LeRA Miles UNEP-World Conservation Monitoring Centre, Cambridge, UK Simon A.H. Milledge Royal Norwegian Embassy, Dar es Salaam, Tanzania

Pantaleo K.T. Munishi, Deo Shirima and Eliakim Zahabu Sokoine University of Agriculture, Chuo Kikuu, Morogoro, Tanzania

Ruth D. Swetnam Conservation Science Group, Department of Zoology, University of Cambridge, Cambridge, UK

Received 14 December 2009. Revision requested 10 March 2010. Accepted 13 April 2010. house gas emissions, provide an income to rural communities and conserve biodiversity. The establishment of the UN-REDD Programme in Tanzania illustrates real-world challenges in a developing country. These include currently inadequate baseline forestry data sets (needed to calculate reference emission levels), inadequate government capacity and insufficient experience of implementing REDD+-type measures at operational levels. Additionally, for REDD+ to succeed, current users of forest resources must adopt new practices, including the equitable sharing of benefits that accrue from REDD+ implementation. These challenges are being addressed by combined donor support to implement a national forest inventory, remote sensing of forest cover, enhanced capacity for measuring, reporting and verification, and pilot projects to test REDD+ implementation linked to the existing Participatory Forest Management Programme. Our conclusion is that even in a country with considerable donor support, progressive forest policies, laws and regulations, an extensive network of managed forests and increasingly developed locally-based forest management approaches, implementing REDD+ presents many challenges. These are being met by coordinated, genuine partnerships between government, non-government and community-based agencies.

Keywords Carbon, Copenhagen, CoP 15, forests, greenhouse gas, REDD+, Tanzania, UNFCCC

\section{Introduction}

T U uman destruction of tropical forests is estimated to 1 contribute up to $17 \%$ of global carbon dioxide emissions, resulting in accelerated global warming (Achard et al., 2004; Gullison et al., 2007; IPCC, 2007; Van der Werf et al., 2009). One mechanism proposed to mitigate these emissions is Reducing Emissions from Deforestation and Forest Degradation in Developing Countries, otherwise known as Reducing Emissions from Deforestation and Forest Degradation (REDD). The recently agreed REDD+ is the original concept of REDD, plus sustainable management of forests 
and the conservation and enhancement of forest carbon stocks. The proposed REDD+ mechanism forms part of an international move to include emissions from habitat change (especially the loss of carbon-rich ecosystems such as forests) in a more comprehensive agreement under the UN Framework Convention on Climate Change (UNFCCC), which it is hoped will become operational in 2012.

At the UNFCCC meeting (CoP 15) in Copenhagen, Denmark, in December 2009, some of the parties developed a draft decision known as the Copenhagen Accord. This accord provides the basis for REDD+ in paragraph 8: 'scaled up, new and additional, predictable and adequate funding as well as improved access shall be provided to developing countries, in accordance with the relevant provisions of the Convention, to enable and support enhanced action on mitigation, including substantial finance to reduce emissions from deforestation and forest degradation (REDD+)' (UNFCCC, 2009a). It is unclear whether these draft commitments will be met by signatory countries as the accord was noted but not adopted by the meeting. The drafting of text on REDD+ continues under the Convention's Ad Hoc Working Group on Long-Term Cooperative Action, which formally broadened the scope of negotiations from REDD to REDD+ at CoP 15. Although various issues are still being debated, there is widespread agreement on principles, the need for environmental and other safeguards, and a phased approach to implementation.

If an international REDD+ mechanism is to be successful, with minimal displacement of greenhouse gas emissions between countries (known as international leakage), it is important that developing countries hosting a large proportion of the world's forest are ready to participate shortly after its launch. Existing UNFCCC decisions on REDD+ encourage developing countries to prepare for an eventual agreement on the topic and developed countries to support them in doing so. National activities to prepare for REDD may involve building of institutional commitment and capacity, design and planning of REDD+ programmes and pilot activities to test the effectiveness of REDD+ measures.

Tanzania currently benefits from donor funding to help it establish REDD+ actions in the country. These include a 100 million NOK (c. USD 80 million) commitment from the Government of Norway to support national REDD strategy development, sub-national pilot projects, research and capacity building, investments in measuring, reporting and verification, private sector engagement, and the establishment and piloting of a Trust Fund (Milledge, 2009). It is also receiving USD 4.28 million from the UN-REDD Programme, also largely funded by Norway, which is a collaborative partnership between three UN agencies (the Food and Agriculture Organization (FAO), the United Nations Development Programme (UNDP) and the United Nations Environment Programme (UNEP)), that operates in nine pilot countries (UN-REDD, 2009). Other donor support includes preparatory funding for the development of a Readiness Preparation Proposal from the World Bank's Forest Carbon Partnership Facility, for the development of a national forest monitoring system (Government of Finland, c. USD 5 million) and for improving forest management in the Eastern Arc Mountains from the German Climate Change Initiative (c. USD 3.5 million).

Here, we focus on the UN-REDD Programme. This has the overall goal to test whether carefully structured payment mechanisms, and relevant capacity building, can create incentives to ensure actual, lasting, achievable, reliable and measurable emission reductions whilst also maintaining and improving the other ecosystem services that forests usually provide. Proposed interventions under the UN-REDD Programme are coordinated with other REDD+ activities through the national REDD+ Task Force.

Here we outline the challenges facing Tanzania in implementing REDD+. Existing summary data are presented on the forests of Tanzania, focusing on issues of greatest relevance to the facilitation of REDD+: amounts of forest remaining, rates of forest loss from deforestation, levels of forest degradation and the consequences for carbon sequestration and storage. Ways to address challenges in implementing REDD+ are summarized and linkages at the field level between REDD+ and existing forest management programmes, for example the Participatory Forest Management Programme, are summarized. Although this case study relates to Tanzania it has relevance for other tropical developing nations preparing for REDD+.

\section{Tanzanian forest data in relation to the needs of REDD+}

The outline REDD+ process requires participating developing countries to calculate their area of forest and rates of deforestation and degradation, and hence reference baseline emission levels. The number of guidance documents for calculating emissions is rapidly increasing (e.g. Penman et al., 2003a,b; IPCC, 2006; GOFC-GOLD, 2009; UNFCCC, $2009 \mathrm{~b}, \mathrm{c})$. There is common agreement that a country participating in the REDD+ mechanism will be recompensed based on positive changes to its forest carbon stocks but no decision has been taken under UNFCCC on whether the financial mechanism involved will be market-and/or fundbased. Tanzania favours a fund-based system (Otsyina et al., 2008; URT, 2009). Available national information, summarized below, indicates what still needs to be done in Tanzania and illustrates the scale of the challenge facing tropical developing countries preparing to implement REDD+.

\section{Forest area}

Tanzania has c. 35 million ha of evergreen forests and deciduous woodlands, extending across $>38 \%$ of the terrestrial 
mainland (MNRT, 1998, 2001; FAO, 2006; Zahabu et al., 2009). Forest in Tanzania is defined in the Tanzanian Forest Act (URT, 2002) as an 'area of land with at least $10 \%$ tree crown cover, naturally grown or planted, and/or $50 \%$ or more shrub and tree regeneration cover; and includes all forest reserves of whatever kind declared or gazetted under this Act and all plantations'. The total forest area can be divided into a number of different ecological forest types according to the WWF ecoregions classification (Burgess et al., 2004; Table 1, Fig. 1). The different forest types contain carbon in different densities (FBD, 2007) and also vary in their biological significance and value to people's livelihoods (Burgess \& Clarke, 2000; Burgess et al., 2007; Campbell et al., 2008; FBD, 2008; Kapos et al., 2008).

\section{Deforestation}

Deforestation in UNFCCC terms involves a permanent change to another land use (Penman et al., 2003a). The forest area in Tanzania is declining as a result of agricultural expansion, uncontrolled wild fires, intense livestock grazing, illegal mining and charcoal making (FBD, 2008). The official Tanzanian deforestation rate is contained in the Global Forest Resources Assessment of 2005 (FAO, 2006). For this, Tanzania used data interpreted from 1984 satellite imagery (Millington \& Townsend, 1989) and compared these with 1995 data (Hunting Technical Services, 1997) for the determination of land cover changes. The annual deforestation was calculated as 412,279 ha for forest cover and for woodlands as 1,174,538 ha. More detailed and more recent deforestation rates are only known for some forest types, typically over the period 1990-2000 (FBD, 2005; Table 1). As an example, the area of closed canopy forest in the Eastern Arc Mountains declined by $1 \%$ over 10 years, whereas coastal forests declined by $7 \%$ and miombo woodland by $13 \%$ over the same period (FBD, 2005). Several forest types in Tanzania have no reliable estimate of their area or rate of loss (Table 1).

\section{Degradation}

The UNFCCC definition of forest degradation is 'direct human-induced long-term loss (persisting for $\mathrm{X}$ years or more) of at least $\mathrm{Y}$ per cent of forest carbon stocks (and forest values) since time (T) and not qualifying as deforestation' (Penman et al., 2003a). Therefore, even an area that is temporarily devoid of trees may still qualify as degraded forest if those trees are likely to grow back.

Tanzanian forests are being degraded because of unsustainable pole-cutting, logging and firewood collection, overgrazing and wildfires. Around towns, forests are being heavily affected by charcoal harvesting (Ahrends, 2005; Milledge et al., 2007). However, the extent of degradation and its impact on the carbon stored in Tanzanian forests has mainly been presented in unpublished case studies
(FBD, 2007; Malimbwi et al., 2007; Van Beukering et al., 2007). Great effort is required to develop a robust understanding of the level of degradation in the woodland and forest resources of Tanzania. Moreover, a better understanding and analysis of the drivers of forest degradation is required as part of developing mitigation interventions at local and national levels to ensure improved land-use change. This kind of understanding is also crucial for subsequent development of management techniques for ecological restoration (Marshall, 2008).

\section{Carbon storage and loss}

Amounts of carbon stored in different forest types in Tanzania are only partly known (FBD, 2007; Table 1), the carbon density of many tree species is not known, and robust forest-specific equations to convert standard tree diameter and height measurements to biomass carbon have only been established for some forest types (Malimbwi \& Luoga, 1994; Mattia \& Malimbwi, 1998; Chamshama et al., 2004; Munishi \& Shear, 2004; Malimbwi et al., 2005). Firstorder, field-survey based carbon density estimates are lacking for several forest ecoregions (see Burgess et al., 2004 for terminology): East Africa montane forests, Albertine rift forests, southern rift forests, mangrove forest, Victoria Basin forest-savannah mosaic, and northern and southern AcaciaCommiphora bushlands and thickets (Fig. 1). Because of these gaps in knowledge, global data sets have been used to generate a preliminary map of carbon density across Tanzania (Fig. 2).

Tanzania currently only has sufficient data to calculate carbon loss approximately from deforestation for a limited number of its forest types. For the Eastern Arc Mountains the past 20 years of deforestation have resulted in the loss of c. 34 million $t$ of carbon, c. 1.7 million t per annum (Table 1). Much of this comes from the woodlands and forests outside the network of government-, village- or co-managed reserved areas (FBD, 2007; Hall et al., 2009; Scharlemann et al., 2010).

The impact of degradation on carbon storage is even less well known and for most forest types there are no data on the impacts of degradation on carbon storage (Table 1). In the Eastern Arc forests degradation is estimated to reduce carbon storage by 65 million $t$ from the network of 150 reserves within that ecoregion (Table 1). Enhanced management of the government, village and partnership reserves, which contain at least $85 \%$ of the remaining forest and are often degraded, could reverse most of these losses.

\section{Forest management regimes in Tanzania}

The forested land is under various management regimes (Zahabu et al., 2009). More than half the remaining forest is within village or general land categories (Fig. 3). The 
TABLE 1 The nine main forest types in Tanzania, with a brief description of their structure, height and biological values, historical (pre-1850) area, area in 1990 and 2000 (where known), percentage loss from 1990 to 2000, estimates of carbon (stem, branches and roots; not soil carbon) in pristine and degraded forest, and indicative loss through degradation.

\begin{tabular}{|c|c|c|c|c|c|c|c|c|}
\hline Forest type & Description & $\begin{array}{l}\text { Historical } \\
\text { area (ha) }\end{array}$ & $\begin{array}{l}\text { Area in } \\
1990 \text { (ha) }\end{array}$ & $\begin{array}{l}\text { Area in } \\
2000 \text { (ha) }\end{array}$ & $\begin{array}{l}\text { \% loss } \\
1990-2000\end{array}$ & $\begin{array}{l}\text { Carbon } \\
\text { in pristine } \\
\text { forest }\left(\mathrm{t} \mathrm{ha}^{-1}\right)^{1}\end{array}$ & $\begin{array}{l}\text { Carbon in } \\
\text { degraded } \\
\text { forest }\left(\mathrm{t} \mathrm{ha}^{-1}\right)^{1}\end{array}$ & $\begin{array}{l}\text { Loss } \\
\left(\mathrm{t} \mathrm{ha}^{-1}\right)^{1}\end{array}$ \\
\hline Miombo woodlands ${ }^{2,3}$ & $\begin{array}{l}\text { Closed canopy forest on poor } \\
\text { soils; deciduous in dry season; to } \\
30 \mathrm{~m} \text {; moderate biodiversity } \\
\text { value }\end{array}$ & $\begin{array}{l}40 \% \text { of land area } \\
\text { (estimate) }\end{array}$ & Only partial data ${ }^{2}$ & Only partial data ${ }^{2}$ & $13^{2}$ & $70^{1,3}$ & $40^{1,3}$ & $30^{1,3}$ \\
\hline Acacia savannah & $\begin{array}{l}\text { Open canopy forest in dry areas; } \\
\text { deciduous in dry season; to } 20 \mathrm{~m} \text {; } \\
\text { moderate biodiversity value }\end{array}$ & No data & No data & No data & & $\begin{array}{l}\text { No estimates } \\
\text { available }\end{array}$ & $\begin{array}{l}\text { No estimates } \\
\text { available }\end{array}$ & \\
\hline $\begin{array}{l}\text { Eastern Arc Mountains } \\
\quad \text { (upper montane \& } \\
\text { montane forest areas) }\end{array}$ & $\begin{array}{l}\text { Closed canopy evergreen forest } \\
\text { on crystalline mountains; to } 40 \\
\text { m; exceptional biodiversity value }\end{array}$ & $1,799,200$ & 355,000 & 353,100 & $1^{5}$ & $306^{1,6}$ & $83^{1,6}$ & $223^{1,6}$ \\
\hline Kenya/Tanzania mountains & $\begin{array}{l}\text { Closed canopy evergreen forest } \\
\text { on volcanic mountains; to } 40 \mathrm{~m} \text {; } \\
\text { high biodiversity value }\end{array}$ & No data & No data & No data & & $\begin{array}{l}\text { No estimates } \\
\text { available }\end{array}$ & $\begin{array}{l}\text { No estimates } \\
\text { available }\end{array}$ & \\
\hline $\begin{array}{l}\text { Eastern African coastal } \\
\text { forest mosaic }\end{array}$ & $\begin{array}{l}\text { Semi-evergreen closed canopy } \\
\text { forest within a mosaic of other } \\
\text { vegetation types located along E } \\
\text { coast; to } 30 \mathrm{~m} \text {; high biodiversity } \\
\text { value }\end{array}$ & $1,500,000$ & 704,200 & 684,100 & $7^{7}$ & $157^{1}$ & $33^{1}$ & $124^{1}$ \\
\hline Guineo-Congolian forests ${ }^{3,8}$ & $\begin{array}{l}\text { Closed canopy evergreen forest } \\
\text { found in NW lowlands; to } 50 \mathrm{~m} \text {; } \\
\text { high biodiversity value }\end{array}$ & $<1,000,000$ & No data & 670,000 & & $\begin{array}{l}\text { No estimates } \\
\text { available }\end{array}$ & $\begin{array}{l}\text { No estimates } \\
\text { available }\end{array}$ & \\
\hline Mangrove forests ${ }^{9}$ & $\begin{array}{l}\text { Closed canopy evergreen forest } \\
\text { in marine mud; to } 25 \mathrm{~m} \text {; low } \\
\text { biodiversity value }\end{array}$ & No data & 109,500 & 108,100 & $2^{9}$ & $\begin{array}{l}\text { No estimates } \\
\text { available }\end{array}$ & $\begin{array}{l}\text { No estimates } \\
\text { available }\end{array}$ & \\
\hline Albertine rift forests & $\begin{array}{l}\text { Closed canopy evergreen forest } \\
\text { on crystalline mountains; to } 40 \\
\text { m; high biodiversity value }\end{array}$ & No data & No data & No data & & $\begin{array}{l}\text { No estimates } \\
\text { available }\end{array}$ & $\begin{array}{l}\text { No estimates } \\
\text { available }\end{array}$ & \\
\hline Southern rift forests & $\begin{array}{l}\text { Closed canopy evergreen forest } \\
\text { on crystalline mountains; to } 40 \\
\text { m; high biodiversity value }\end{array}$ & No data & No data & No data & & $\begin{array}{l}\text { No estimates } \\
\text { available }\end{array}$ & $\begin{array}{l}\text { No estimates } \\
\text { available }\end{array}$ & \\
\hline
\end{tabular}

${ }^{1} \mathrm{FBD}(2007)$

${ }^{2}$ Estimated from land cover maps

${ }^{3}$ From a partial sample of miombo in eastern Tanzania (FBD, 2005)

${ }^{4}$ Based on plots studied by P.K. Munishi \& D. Shirima

${ }^{5} \mathrm{FBD}$ (2005); Hall et al. (2009)

${ }^{6}$ Munishi \& Shear (2004)

${ }^{7}$ Tabor et al. (2010)

${ }^{8}$ GEF Cross Borders Project (2000-2004)

${ }^{9}$ Wang et al. (2003) 


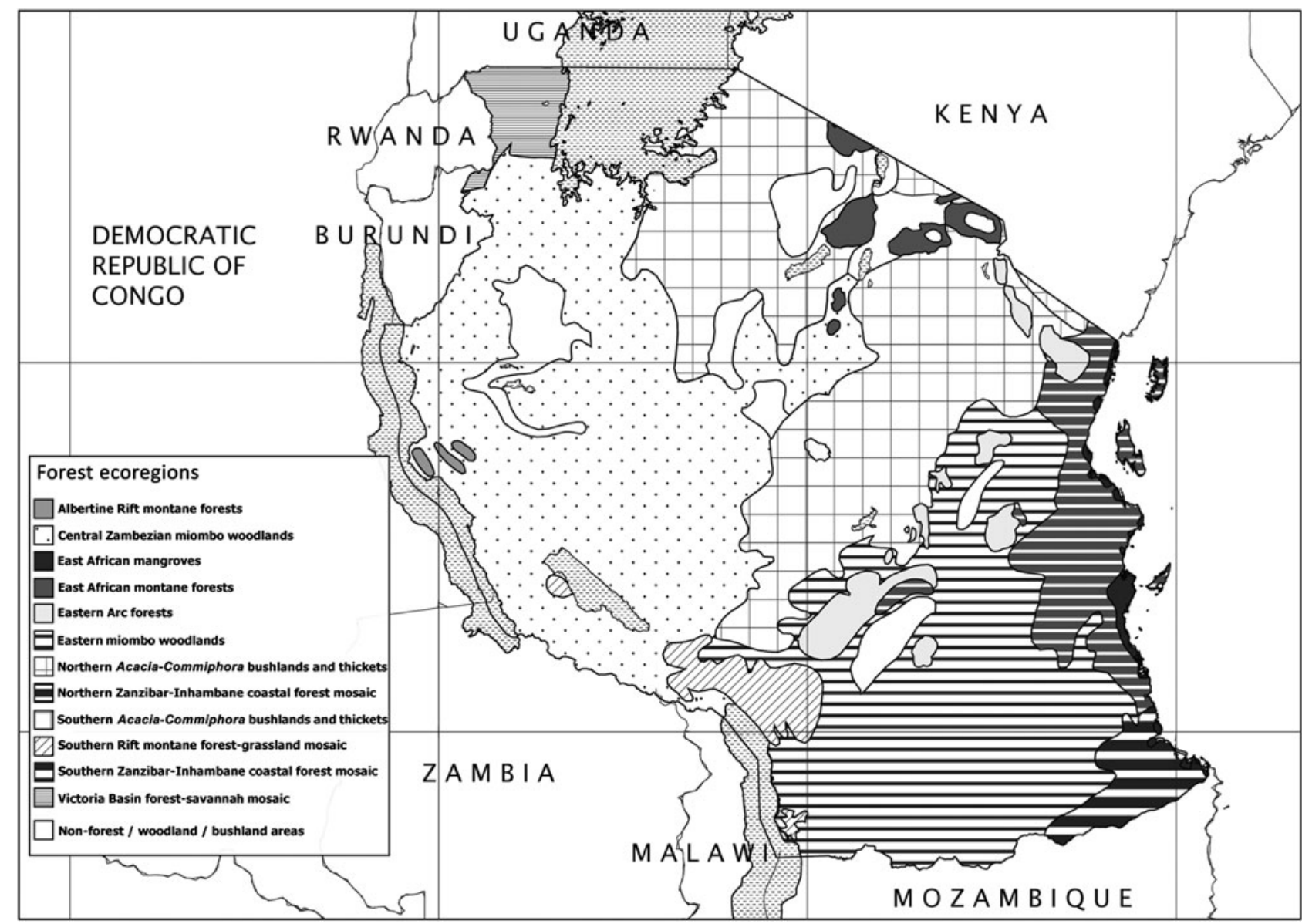

FIG. 1 The forest ecoregions of Tanzania (after Burgess et al., 2004).

remainder is within various forms of protected area, including national parks, game reserves, nature reserves and various kinds of forest reserves (Fig. 3). The Forestry and Beekeeping Division of the Ministry of Natural Resources and Tourism and District Council Natural Resources Departments manage $>600$ reserves covering almost 10 million ha. These agencies have inadequate budgets and lack equipment, and many of the reserves are not actively managed or patrolled and hence often become degraded. More funding and training in the management of these areas could reverse degradation and improve their sequestration and storage of carbon. The same is also true to some extent for the national parks and game reserves, although the agencies managing these areas tend to have better funding and capacity, and hence degradation within their reserves is lower, especially within the national parks. However, most forest loss occurs outside reserves in the village and general lands, where the expanding human population lives (FBD, 2005; Hall et al., 2009; Tabor et al., 2010).

\section{Conceptual background to the UN-REDD Programme in Tanzania}

The development of the UN-REDD Programme for Tanzania was based on a conceptual diagram of how REDD+ could work in Tanzania (termed the REDD+ production chain; Fig. 4). The four quadrants of this production chain are described below. The programme aims to address key gaps and needs in this production chain to start it working.

Quadrant 1: Sustainable forest management at field level

The first quadrant (Fig. 4, bottom right) outlines the importance of sustainable management of forests in the implementation of REDD+. To be able to plan for sustainable management it is necessary to identify forest areas and quantify carbon pools and have a detailed knowledge of land ownership and governance at the district, village and private sector levels.

\section{Quadrant 2: Regulation and governance}

The second quadrant (Fig. 4, top right) focuses on the national-level regulations and governance structures that provide the overall credibility, sustainability and scale of economics in support of potential REDD+ interventions. Important elements in Tanzania are: (1) cross-sectoral coordination to avoid undue competition over land-use 


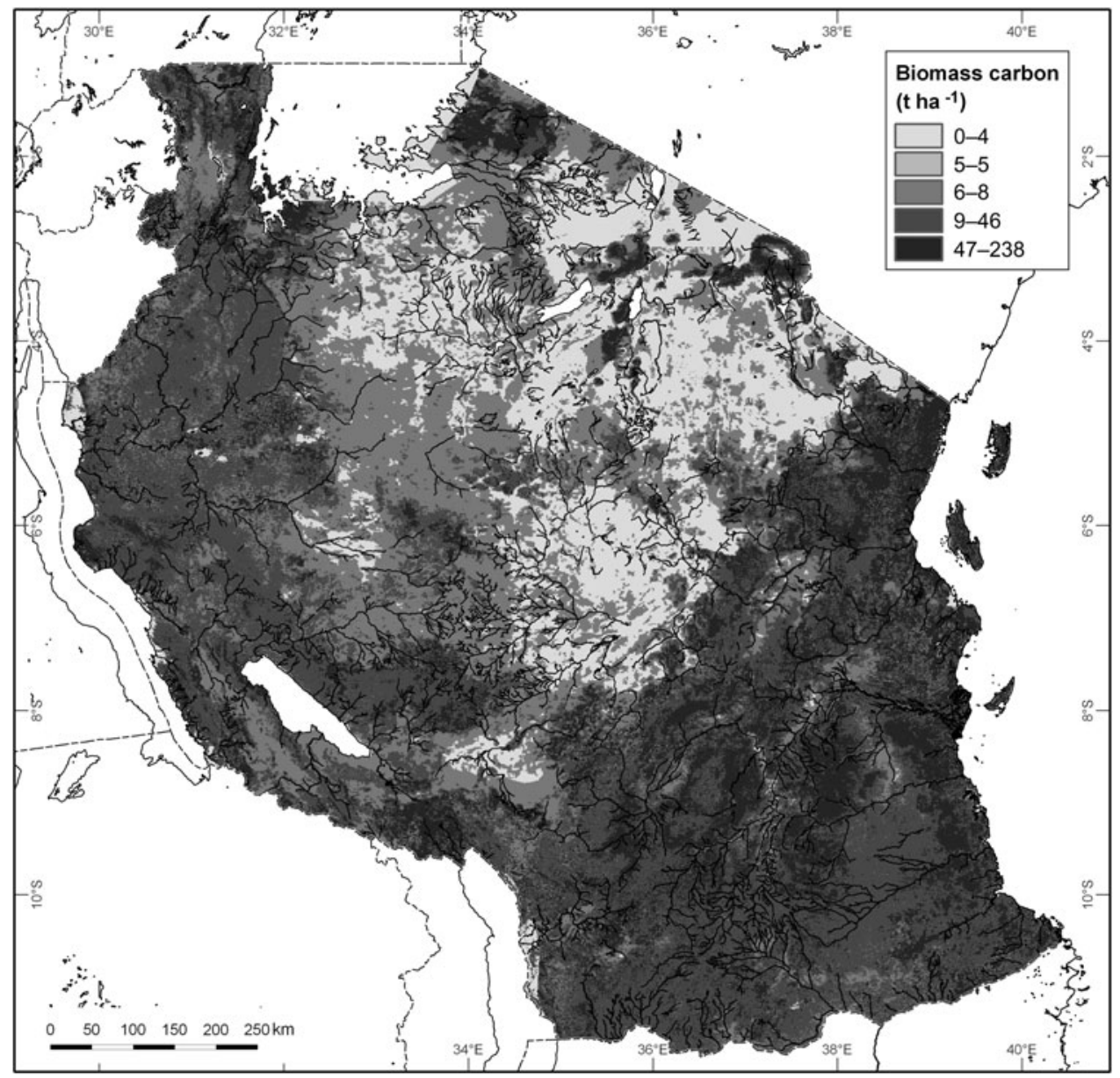

FIG. 2 Initial map of biomass carbon in Tanzania (from Miles et al., 2009). The above ground biomass was derived from a model for tropical Africa, which uses remotely sensed MODIS NBAR data from 2000-2003 (Baccini et al., 2008), and below ground biomass estimated using ecosystem-specific conversion factors. There were no model data for zones with $<9 \mathrm{t}$ of above ground biomass per ha. Values from a global biomass carbon map (Ruesch \& Gibbs, 2008) were substituted in these zones.

allocations, (2) development of a legal framework for the ownership of carbon and emission reductions and payment distribution systems, and (3) development of cost-efficient measuring, reporting and verification systems that fulfil REDD+ needs (Penman et al., 2003a).

\section{Quadrant 3: Market or fund access}

The third quadrant (Fig. 4, top left) contains the key elements for positioning Tanzania in a potential international REDD+ market or as a credible recipient of funds from a potential REDD+ fund. However, these requirements are not yet clear because the mechanisms for a market-based or fund-based approach have not yet been finalized. It is also possible that a potential market or fund for carbon sales will place requirements on forest managers marketing potential emission reductions.

\section{Quadrant 4: Funds transfer and management}

The fourth quadrant (Fig. 4, bottom left) highlights the key elements for contracting, funds transfer, equitable payment distribution and funds management. Different solutions for contracting can be taken depending on the set-up of the national REDD+ framework and whether a national or sub-national (project-based) approach has been established. Emissions reductions may be sold by national-level operators (private or governmental) that have bundled emissions reductions from many sites, or directly by the site-scale producers of reductions depending on what is agreed by national and international negotiations. The Tanzanian government would prefer to use the existing forest management devolution programme to implement REDD+, as detailed below.

\section{Development of the UN-REDD Programme in Tanzania}

The UN-REDD Programme aims to address the issues identified in the REDD+ production chain (Fig. 4) to help Tanzania become ready to enter the official and voluntary $\mathrm{CO}_{2}$ emission trading systems, reverse deforestation and degradation, and conserve and enhance forest carbon stocks. 


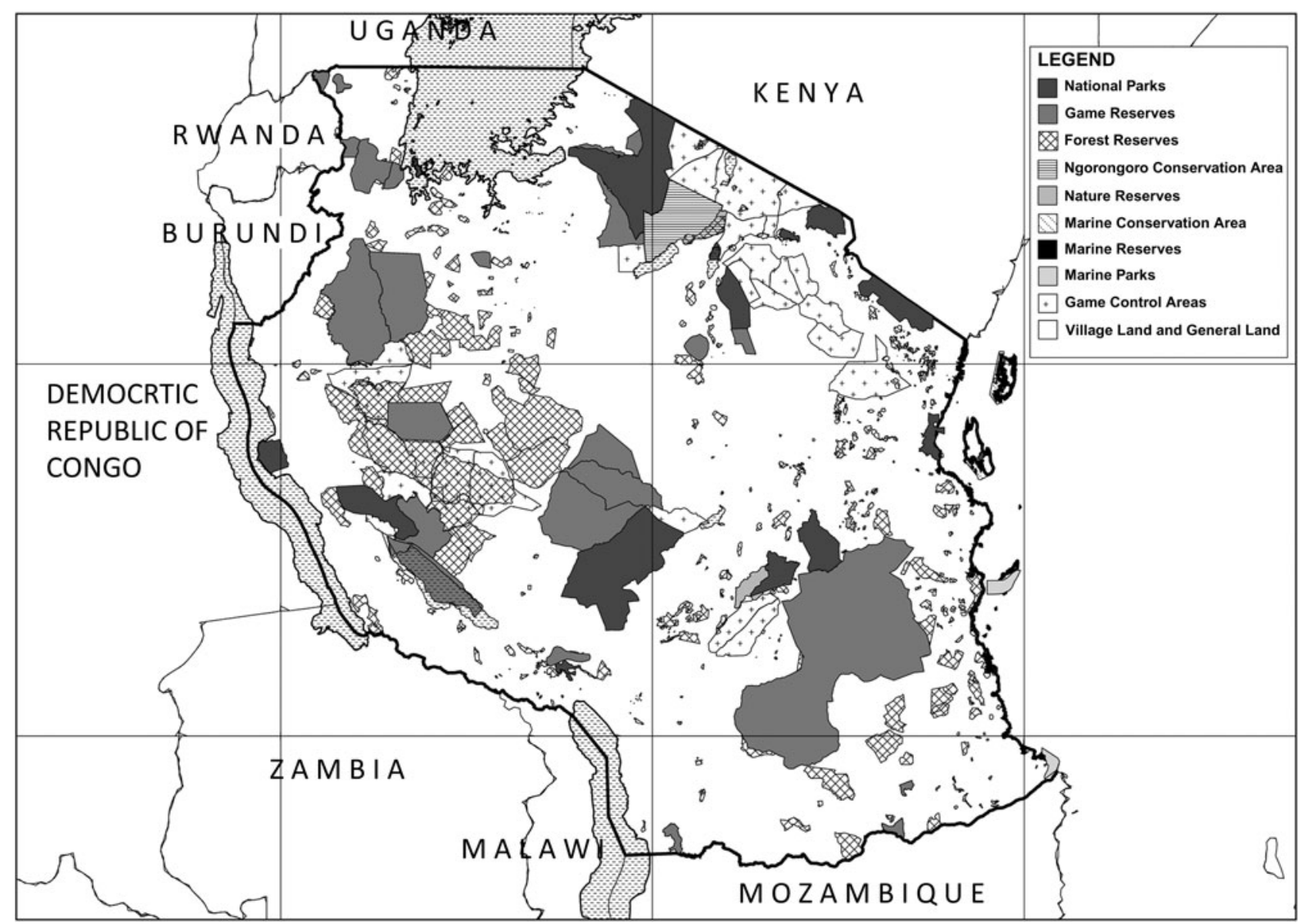

FIG. 3 The reserve network and the surrounding village and general lands of Tanzania (modified from WDPA, 2009).

The main challenges faced are: (1) a lack of relevant data to set REDD+ baselines (see above), (2) a lack of capacity within the various agencies in Tanzania to implement REDD+ and carry out robust monitoring of carbon stock change, (3) a need for REDD+ mechanisms to be tested, and (4) a widespread lack of understanding of the issues surrounding REDD+.

These challenges have been translated into four outcomes in the UN-REDD National Joint Programme document, which has received USD 4.28 million in funding from the UN-REDD Multi-Donor Trust Fund. This support will be channelled to the three UN agencies working in Tanzania (UNDP, FAO and UNEP) under the so-called one UN approach. These three UN agencies are working together with the Forestry and Beekeeping Division under the coordination of the REDD+ Task Force. UN-REDD support has been fully aligned to existing forest laws and the national REDD+ framework of 2009 (REDD Tanzania Initiative, 2009). It has also taken on board the views of bilateral and multilateral donors, international and local NGOs and representatives of Tanzanian indigenous peoples who sit on the UN-REDD Policy Board.

\section{Proposed outcomes of the UN-REDD Programme in Tanzania (2009-2011)}

The first proposed outcome of the Programme is a national governance framework for REDD+ and strengthened institutional capacities. Within Tanzania climate change is treated as a cross-cutting issue and hence involves various government sectors. The Vice President's Office, Department of Environment, and the Forestry and Beekeeping Division have established a National REDD Task Force to assist coordination. This task force also aims to develop a national strategy for REDD+ and promote the voluntary carbon market. UN-REDD support aims to build capacity to implement REDD+ within the Forestry and Beekeeping Division. It will also help finalize the national REDD+ framework and strategy for the country and will clarify roles, structures and social safeguards for effective implementation of REDD+ in Tanzania.

The second outcome is increased capacity for capturing REDD+ elements within national measuring, reporting and verification systems. This component aims to assist in the development of a system for measuring and monitoring forest cover, forest change, carbon stocks and carbon 


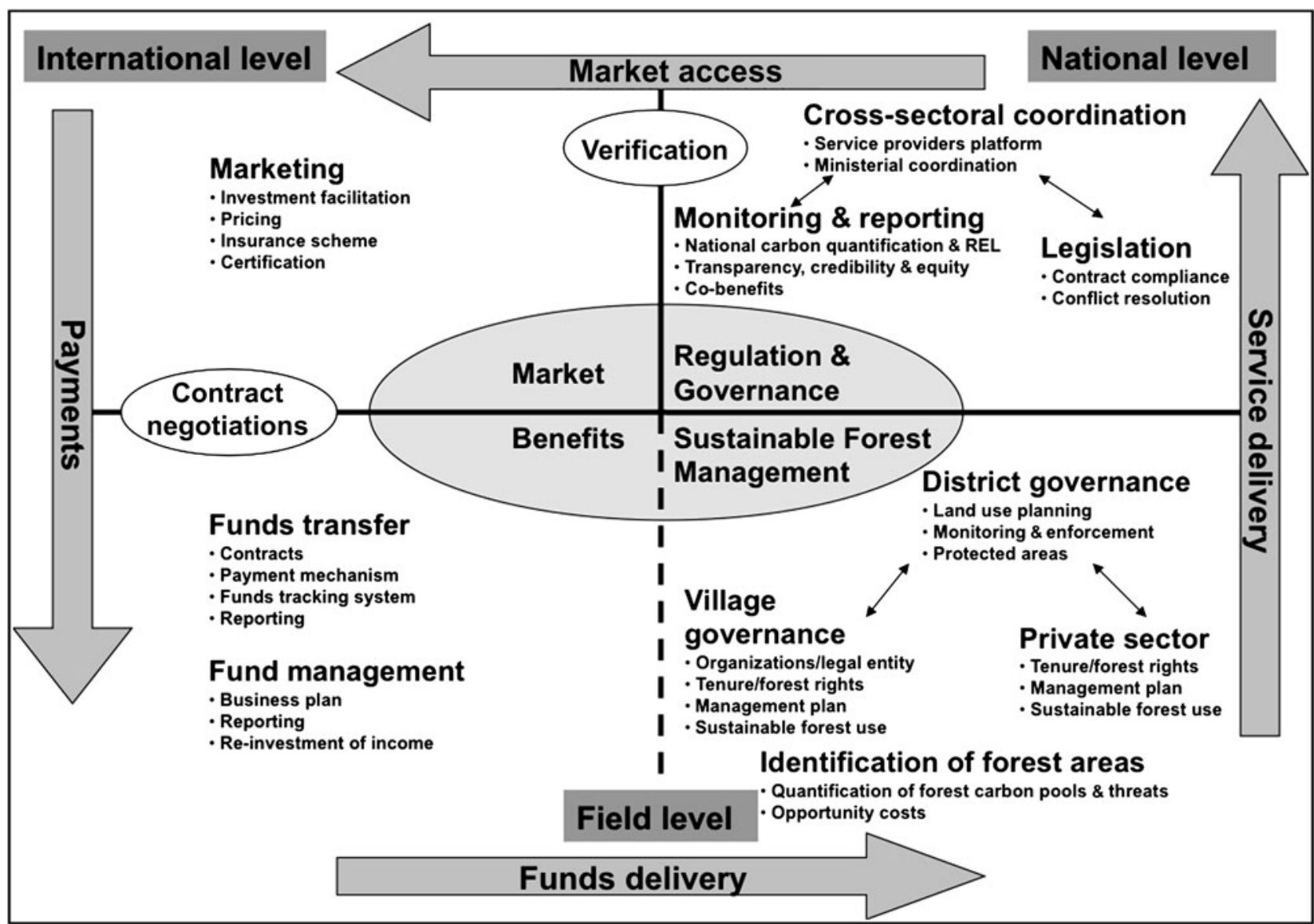

FIG. 4 Proposed national structure of REDD+ implementation in Tanzania (termed the REDD+ production chain). For explanation of the four quadrants, see text.

emission levels, building on a new national forest resource and monitoring assessment project. Potential co-benefits of REDD+ (biodiversity, ecosystem services and social benefits) will also be assessed. Capacity building will be provided in the form of training on remote sensing and mapping. UN-REDD measuring, reporting and verification work will be linked to an existing national forest inventory project and to Norwegian government support to carbon mapping through universities and civil society. A nationwide system of sampling clusters will be measured to assess forest condition and degradation. Current and historic extent of forest resources will also be mapped.

The third outcome is improved capacity to manage REDD+ and provide other forest ecosystem services at district and local levels. This component aims to build the capacity of the decentralized forest sector to implement REDD+. Pilot activities will be initiated in different forest types. These will be aligned to the broader support for piloting REDD+ projects being funded by the Norwegian Embassy to civil society organizations in Tanzania. Work will primarily be undertaken at the village level and outside formal government-managed reserves but some effort will also be made to test ways to improve reserve management, including where reserves are co-managed with communities, and hence allow forest condition to improve and capture more carbon.

The fourth outcome is broad-based stakeholder support for REDD+ in the country. As REDD+ is a new, rapidly evolving concept there is a need to inform Tanzanian stakeholders about the practicalities of this new approach to forest conservation. This relates particularly to payment systems for avoided deforestation and degradation as this is unfamiliar to local and village governments and to communities. The mechanism of making and monitoring payments is perhaps the most difficult part of REDD+ to implement at the field level.

\section{Implementation and monitoring}

One viable approach for implementing REDD+ in Tanzania would be to work with the protected area authorities and invest in better law enforcement and management of the existing forest reserves and game reserves. These two categories of state-managed reserves suffer from degradation and 
a reduction in biomass, especially the forest reserves. Improved management would lead to substantial increases in biomass within the reserves over time, and hence they could function as significant carbon stores while also continuing to provide their other ecosystem services and biodiversity conservation functions (Marshall, 2008).

Another existing forest management strategy in Tanzania provides a good example of how to build upon existing forest management approaches to implement REDD+. During the past 20 years Tanzania has become one of the leading countries in developing forest management practices based on local participation (Blomley, 2006; Blomley \& Ramadhani, 2006; Lund \& Treue, 2008; Blomley \& Iddi, 2009). Participatory forest management in Tanzania builds on the country's local government institutional framework, which formalizes the role of local communities through elected village councils and village assemblies. It also builds upon the country's legal framework for land tenure, which vests these village governance organs with responsibility for managing the village lands within their boundaries.

Tanzanian participatory forest management is of two basic forms. Joint Forest Management involves the comanagement of forest reserves between forest-adjacent villages and government managers, from either the Forestry and Beekeeping Division or district councils. CommunityBased Forest Management is where local villages, or subgroups within the village, are the sole forest manager by virtue of establishing communally reserved forests on village lands. These types of management are defined and described in the Tanzanian National Forestry Policy (MNRT, 1998), Forest Programme (MNRT, 2001) and Forest Act (URT, 2002).

By 2008 participatory forest management covered c. 4.1 million ha, with c. 1.7 million ha under Joint Forest Management and 2.4 million ha under Community-Based Forest Management (Blomley et al., 2008). In total c. 13\% of all the forest in Tanzania was under participatory forest management arrangements by 2008 , involving more than 2,300 villages. The area and the number of villages involved continue to expand.

REDD+ piloting in Tanzania seeks to build on the participatory forest management experience and to test ways to transfer benefits from the national government to communities managing forests. The lessons learned will be critical with regard to designing and implementing REDD+ in Tanzania and other developing countries (Murdiyarso \& Skutsch, 2006; Chhatre \& Agrawal, 2009). However, the participatory forest management system has limitations, largely because of (1) governance deficiencies at the national, district and village levels, (2) insufficient government incentives and benefits to local people to continue their forest management work, (3) slow and inefficient work practices and (4) occasional corruption at various levels. The challenges are reviewed by Meshack et al.
(2006), Blomley \& Iddi (2009) and Persha \& Blomley (2009). The REDD+ system needs to build upon these lessons and become more efficient and targeted, and, if distributed equitably, REDD-generated funds have the potential to increase the success of participatory forest management by providing the financial incentive necessary to create permanence.

\section{Community monitoring of REDD+ in Tanzania}

The monitoring of the implementation of REDD+ in Tanzania will need to operate at two levels. The national baseline and calculation of reference emission levels and potential emission reductions will be developed using remote sensing and a network of forestry plots, as outlined in Outcome 2 of the UN-REDD project. However, this approach will struggle to provide the detail required to assess the implementation of community-level forest conservation interventions. In these cases, alternative locally based or community forest management approaches are more likely to be successful.

Locally based monitoring involves local people or local government staff directly in data collection and interpretation and employs methods that are relatively simple and cheap and require few other resources (Danielsen et al., 2005, 2008; Van Laake et al., 2009). It has been shown that local people can count trees, measure their girth and identify the species accurately (Skutsch et al., 2009) and cost-effectively, thus allowing the collection of large volumes of data conforming to Intergovernmental Panel on Climate Change guidelines (Penman et al., 2003a; KTGAL, 2010). Locally based monitoring can also help build capacity and cooperation between local people and outside authorities and can thereby stimulate local action and result in rapid forest management interventions (Danielsen et al., 2008). These approaches can also monitor social and governance aspects of community-based natural resource management (Stuart-Hill et al., 2005). This includes the extent to which funds are fairly distributed within communities, thereby addressing equity and poverty issues. Using locally based monitoring methods can help to address the concerns of local people that their existing forest use rights and benefits will be undermined by topdown REDD+ implementation.

However, there will also, as with monitoring by scientists, be a need for a cost-effective system of verification or auditing of community-based monitoring as part of the measuring, reporting and verification process, such as through spot checks of the data. This is to ensure that the results from community monitoring can be trusted for the purposes of a payment scheme based on verified emissions reductions. A further challenge will be to ensure that community monitoring in community-managed areas is also integrated with wider monitoring to assess net changes 
in deforestation and degradation across large areas and to ensure that there is no leakage of deforestation and degradation outside community-managed areas.

\section{Discussion}

The implementation of REDD+ in Tanzania faces a number of challenges: a lack of data and technical capacity, the need for coordination at the national level and, if international negotiations render it necessary, guidelines and assistance on how to instigate a market-orientated approach to REDD+ within both centralized and decentralized government agencies. These challenges will need to be overcome if REDD+ is to succeed.

In addition to the ongoing Tanzanian National Forestry Assessment, and the carbon management and measurement projects that will be supported by the Royal Norwegian Embassy, additional relevant data may come from global sources on deforestation and carbon stocks (Gibbs et al., 2007; Hansen et al., 2008; Schmitt et al., 2009). Techniques are also rapidly being developed to assist countries to develop reliable regional to sub-national data (Baccini et al., 2008; Mitchard et al., 2009; Tabor et al., 2010). Ground-based surveys will be needed to evaluate these assessments (Lewis et al., 2009). In addition to the forestbased carbon in Tanzania there is also organic carbon stored in wetlands, for example in the localized peatlands found in the Southern Highlands, particularly Sao Hill, and in Ukinga (Nshubemuki, 1993).

In terms of coordination, one of the key activities is the development of a national REDD+ strategy in anticipation of a post-2012 climate change agreement that will include a new global facility for REDD+ (REDD Tanzania Initiative, 2009). This work is being coordinated by the Tanzanian REDD+ Task Force, which is also compiling a list of all known REDD+ projects in the country.

It is not yet known what financial mechanism will be used to receive and disperse REDD+ incentive payments in Tanzania. The Tanzanian government favours a fundbased approach, which would potentially reduce the opportunities for the private sector but would fit with the realities of the land ownership system in Tanzania, where there are few privately managed forest areas. The voluntary carbon market and the seed funding from the Norwegian government and UN-REDD will provide ways to test financial mechanisms for REDD+ in Tanzania.

In Tanzania there are four main ways that sustainable forest management aspects of REDD+ may be implemented (Fig. 1, bottom right quadrant). Firstly, through the State-owned protected areas (avoiding and reducing deforestation and, especially, degradation in reserves). Secondly, through community forestry approaches. In particular, the participatory forest management approach could provide ways to pilot REDD+ and, if the trials are successful, the approach could be spread rapidly across the country at the community level, especially if the capacity of the districts is improved. Incorporating this prior experience of implementing participatory forest management (Meshack et al., 2006) into the development of REDD+ projects could improve implementation in Tanzania. Thirdly, through the promotion of agroforestry and conservation agriculture, as unsustainable subsistence agriculture and expanding commercial agriculture are major threats to the forests. Fourthly, through State-owned plantations and private forestry, the expansion of which may be spurred by REDD+ incentives. The latter also highlight the need to consider carefully biodiversity conservation prerogatives.

The ownership and control over land and thus forest are of importance for the implementation of REDD+ in Tanzania. All land in the country is held in trust by the President on behalf of the nation. The two Land Acts (1999) divide land resources into three categories: reserved, village and general land (URT, 1999a,b). The 'Land Act' deals with the management of reserved land and general land whereas the 'Village Land Act' is concerned with village land. Sixteen million of the 35 million ha of forest land in Tanzania are unreserved, and most of these forests are on village lands. Village land is occupied by people and organizations, either through a Granted Right of Occupancy or through a Customary Right of Occupancy. But occupancy does not mean that the occupant owns the land: they only hold rights over it (Wily, 2003). There is no freehold in Tanzania and land cannot be bought or sold outright; only the derivative rights to occupy the land can be sold. With Granted Rights of Occupancy, this right is bound to a designated lease period of a maximum of 99 years (Lovett, 2003; Wily, 2003). In contrast, Customary Rights of Occupancy apply only to village land and may be held indefinitely. In this context, forest land tenure in Tanzania is defined as a combination of legally or customarily defined forest ownership rights and arrangements for the management and use of forest resources. This provides further challenges for the implementation of REDD+.

Tanzania is implementing a national forest inventory that will generate remote sensing and plot data on the forests. This national system will provide input to the development of the measuring, reporting and verification system and enable the relevant calculations of forest cover, forest loss and hence emissions levels. In addition, the country has also developed pilot systems of locally based monitoring that involve communities in the collection of data on forest condition and also contribute to securing local forest livelihoods (Topp-Jørgensen et al., 2005; Verplanke \& Zahabu, 2009). These approaches are being tested scientifically (Monitoring Matters, 2010) and at a small cost could potentially deliver forest data from community-managed forest lands to monitor implementation of REDD+ field projects. 
In conclusion, Tanzania has made significant efforts to prepare for REDD+ and, despite shortages of data and limited technical capacity, and some governance shortfalls, will be embarking on pilot projects in 2010. The relevant government agencies are hopeful that REDD+ will be able to assist in solving the problems of deforestation and degradation and in particular that it will build upon an existing national programme of participatory forest management. A number of significant challenges still need to be overcome if the programme is to be successfully implemented in Tanzania, and capacity building and monitoring will be required, but the Tanzanian government is working with NGOs and communities to address these issues, supported by donor funding.

\section{Acknowledgements}

We thank the many foresters and biologists who have contributed to knowledge on Tanzanian forests, which forms the base of the REDD+ programmes in that country, and the UN-REDD Programme for its support. The institutions of the various authors are thanked for allowing their staff to work on the preparation of this article.

\section{References}

Achard, F., Eva, H.D., Mayaux, P., Stibig, H.-J. \& Belward, A. (2004) Improved estimates of net carbon emissions from land cover change in the tropics for the 1990s. Global Biogeochemical Cycles, 18, GB20o8.

Ahrends, A. (2005) Patterns of degradation in lowland coastal forests in Coast Region, Tanzania. MSc thesis, University of Greifswald, Greifswald, Germany.

Baccini, A., Laporte, N., Goetz, S.J., Sun, M. \& Dong, H. (2008) A first map of tropical Africa's above-ground biomass derived from satellite imagery. Environmental Research Letters, 3 , 045011.

Blomley, T. (2006) Mainstreaming Participatory Forestry within the Local Government Reform Process in Tanzania. International Institute for Environment and Development, London, UK.

Blomley, T. \& Iddi, S. (2009) Participatory Forest Management in Tanzania: 1993-2009. Lessons Learned and Experiences To Date. Ministry of Natural Resources and Tourism, Forestry and Beekeeping Division, Dar es Salaam, Tanzania.

Blomley, T., Pfliegner, K., Isango, J., Zahabu, E., Ahrends, A. \& BURGESS, N.D. (2008) Seeing the wood for the trees: an assessment of the impact of participatory forest management on forest condition in Tanzania. Oryx, 42, 380-391.

Blomley, T. \& Ramadhani, H. (2006) Going to scale with participatory forest management: early lessons from Tanzania. International Forestry Review, 8, 93-100.

Burgess, N.D., Butynski, T.M., Cordeiro, N.J., Doggart, N., FJeldSÅ, J., Howell, K. et al. (2007) The biological importance of the Eastern Arc Mountains of Tanzania and Kenya. Biological Conservation, 134, 209-231.

Burgess, N.D. \& Clarke, G.P. (2000) The Coastal Forests of Eastern Africa. IUCN Forest Conservation Programme, Gland, Switzerland, and Cambridge, UK.
Burgess, N., D'Amico Hales, J., Underwood, E., Dinerstein, E., Olson, D., ItouA, I. et al. (2004) Terrestrial Ecoregions of Africa and Madagascar: A Continental Assessment. Island Press, Washington, DC, USA.

Campbell, A., Chenery, A., Coad, L., Kapos, V., Kershaw, F., Scharlemann, J.P.W. \& Dickson, B. (2008) The Linkages between Biodiversity and Climate Change Mitigation. Prepared by UNEP World Conservation Monitoring Centre, Cambridge, UK, for the first meeting of the Second Ad Hoc Technical Expert Group on Biodiversity and Climate Change, Convention on Biological Diversity. UNEP/CBD/AHTEG/BDCC- $2 / 1 / 5$.

Chamshama, S.A.O., Mugasha, A.G. \& Zahabu, E. (2004) Biomass and volume estimation for miombo woodlands at Kitulangalo, Morogoro, Tanzania. Southern African Forestry Journal, 200, 49-60.

Chhatre, A. \& Agrawal, A. (2009) Trade-offs and synergies between carbon storage and livelihood benefits from forest commons. PNAS, 106, 17667-17670.

Danielsen, F., Burgess, N.D. \& Balmford, A. (2005) Monitoring matters: examining the potential of locally-based approaches. Biodiversity and Conservation, 14, 2507-2542.

Danielsen, F., Burgess, N.D., Balmford, A., Donald, P.F., Funder, M., Jones, J.P. et al. (2008) Local participation in natural resource monitoring: a characterization of approaches. Conservation Biology, 23, 31-42.

FAO (Food and Agriculture Organization) (2006) Global Forest Resources Assessment 2005: Progress towards Sustainable Forest Management. FAO, Rome, Italy.

FBD (Forestry and BeEkeEPIng Division) (2005) Forest Area Assessment for the Eastern Arc Mountains. Forestry and Beekeeping Division, Ministry of Natural Resources and Tourism, Dar es Salaam, Tanzania.

FBD (Forestry and Beekeeping Division) (2007) Carbon Ecological Services. Forestry and Beekeeping Division, Ministry of Natural Resources and Tourism, Dar es Salaam, Tanzania.

FBD (Forestry and BEEKEEPING Division) (2008) Eastern Arc Strategy: Main Document. Forestry and Beekeeping Division, Ministry of Natural Resources and Tourism, Dar es Salaam, Tanzania.

Gibbs, H.K., Brown, Niles, J.O. \& Foley, J.A. (2007) Monitoring and estimating tropical forest carbon stocks: making REDD+ a reality. Environmental Research Letters, 2, 045023.

GOFC-GOLD (Global Observation of Forest and LAND Cover Dynamics) (2009) A Sourcebook of Methods and Procedures for Monitoring and Reporting Anthropogenic Greenhouse Gas Emissions and Removals Caused by Deforestation, Gains and Losses of Carbon Stocks in Forests, Remaining Forests and Forestation. GOFC-GOLD report COP15-1. GOFC-GOLD Project Office, Natural Resources Canada, Alberta, Canada.

Gullison, R.E., Frumhoff, P., Canadell, J., Field, C.B., Nepstad, D.C., Haynoe, K. et al. (2007) Tropical forests and climate policy. Science, 316, 985-986.

Hall, J., Burgess, N.D., Lovett, J., Mbilinyi, B. \& Gereau, R.E. (2009) Conservation implications of deforestation across an elevational gradient in the Eastern Arc Mountains, Tanzania. Biological Conservation, 142, 2510-2521.

Hansen, M.C., Stehman, S.V., Potapov, P.V., Loveland, T.R., Townshend, J.R.G., DeFries, R.S. et al. (2008) Humid tropical forest clearing from 2000 to 2005 quantified by using multitemporal and multiresolution remotely sensed data. PNAS, 105, 9439-9444.

Hunting Technical Services (1997) National Reconnaissance Level Land Use and Natural Resources Mapping. Hunting Technical Services, London, UK. 
IPCC (Intergovernmental Panel on Climate Change) (2006) Guidelines for National Greenhouse Gas Inventories-Volume 4: Agriculture, Forestry and Other Land Use (AFOLU). Http:// www.ipcc-nggip.iges.or.jp/public/2006gl/vol4.html/ [accessed 27 April 2010].

iPCC (Intergovernmental Panel on Climate Change) (2007) Climate Change 2007: The Physical Science Basis. Contribution of Working Group I to the Fourth Assessment Report of the Intergovernmental Panel on Climate Change (eds S. Solomon, D. Qin, M. Manning, Z. Chen, M. Marquis, K.B.M. Tignor \& H.L. Miller), p. 996. Cambridge University Press, Cambridge, UK, and New York, USA.

Kapos, V., Ravilious, C., Campbell, A., Dickson, B., Gibbs, H., Hansen, M. et al. (2008) Carbon and Biodiversity: A Demonstration Atlas. UNEP-World Conservation Monitoring Centre, Cambridge, UK.

KTGAL (Кyoto: Think Global, Act Local) (2010) Community Carbon Forestry. Http://www.communitycarbonforestry.org [accessed 27 April 2010].

Lewis, S.L., Lopez-Gonzalez, G., Sonke, B., Affum-Baffoe, K., B AKER, T.R., OJO, L.O. et al. (2009) Increasing carbon storage in intact African tropical forests. Nature, 457, 1003-1006.

Lovet T, J.C. (2003) Tanzania Forest Law. In Environmental Law and Policy in Africa (eds B. Chaytor \& K. Gray), pp. 151-180. Kluwer Law International, The Hague, The Netherlands.

Lund, J.F. \& Treue, T. (2008) Are we getting there? Evidence of decentralized forest management from the Tanzanian miombo woodlands. World Development, 36, 2780-2800.

Malimbwi, R.E. \& Luoga, E.J. (eds) (1994) Proceedings of the Workshop on Information Acquisition for Sustainable Natural Forest Resources of Eastern, Central and Southern Africa. Faculty of Forestry, SUA, Morogoro, Tanzania.

Malimbit, R.E., Zahabu, E., Madadi, L.M., Monela, G.C., Misana, S. \& Jambiya, G.C. (2005) Tree species preference, volume estimation and charcoal kiln efficiencies in eastern Tanzania miombo woodlands. In Proceedings of the Tanzania Association of Foresters Meeting (ed. S.M.S. Maliondo), pp. 35-39. Tanzania Association of Foresters, Morogoro, Tanzania.

Malimbit, R.E., Zahabu, E. \& Mchome, B. (2007) Situation Analysis of Dar es Salaam Charcoal Sector. Report to WWF Tanzania, Dar es Salaam, Tanzania.

Marshall, A.R. (2008) Assessing and Restoring Biodiversity in Tanzania's Forests: The Case of Magombera. Proceedings of the 6th TAWIRI Scientific Conference, Arusha, Tanzania.

Mattia, S.B. \& Malimbi, R.E. (1998) Volume Equations for Three Mangrove Species in Tanzania. Proceedings of the First Annual Forest Research Workshop, pp. 239-247. Record no. 67. Faculty of Forestry and Nature Conservation, Sokoine University of Agriculture, Morogoro, Tanzania.

Meshack, C., Adhikari, B., Doggart, M. \& Lovett, J.C. (2006) Transaction costs of community-based forest management: empirical evidence from Tanzania. African Journal of Ecology, 44, 468-477.

Miles, L., Kabalimu, K., Bahane, B., Ravilious, C., Dunning, E., Bertzky, M. et al. (2009) Carbon, Biodiversity and Ecosystem Services: Exploring Co-Benefits. Prepared by UNEP-WCMC, Cambridge, UK, and Forestry and Beekeeping Division, Ministry of Natural Resources and Tourism, Dar es Salaam, UN-REDD Programme, Tanzania.

Milled ge, S.A.H. (2009) Getting REDDy in Tanzania: principles, preparations and perspectives. The Arc Journal, 24, 3-6.

Milledge, S.A.H., Gelvas, I.K. \& Ahrends, A. (2007) Forestry, Governance and National Development: Lessons Learned from a Logging Boom in Southern Tanzania. TRAFFIC East/Southern
Africa/Tanzania Development Partners Group/Ministry of Natural Resources and Tourism, Dar es Salaam, Tanzania.

Millington, A. \& Townsend, R. (1989) Biomass Assessment of SADCC Member States. Earthscan, London, UK.

Mitchard, E.T.A., S A a tChi, S.S., Woodhouse, I.H., NANGendo, G., Ribeiro, N.S., Williams, M. et al. (2009) Using satellite radar backscatter to predict above-ground woody biomass: a consistent relationship across four different African landscapes. Geophysical Research Letters, 36, L23401.

MNRT (Ministry of Natural Resources and Tourism) (1998) $\mathrm{Na}$ tional Forest Policy. Forestry and Beekeeping Division of the Ministry of Natural Resources and Tourism, Dar es Salaam, Tanzania.

MNRT (Ministry of Natural Resources and Tourism) (2001) $\mathrm{Na}$ tional Forest Programme. Forestry and Beekeeping Division of the Ministry of Natural Resources and Tourism, Dar es Salaam, Tanzania.

MNRT (Ministry of Natural Resources and Tourism) (2002) Forest Act no. 14. Forestry and Beekeeping Division of the Ministry of Natural Resources and Tourism, Dar es Salaam, Tanzania.

MONitoring MAtTers (2010) Http://www.monitoringmatters.org [accessed 27 April 2010].

Munishi, P.K.T. \& Shear, T.H. (2004) Carbon storage in Afromontane rain forests of the Eastern Arc Mountains of Tanzania: their net contribution to atmospheric carbon. Journal of Tropical Forest Science, 16, 78-93.

Murdiyarso, D. \& Skutsch, M. (eds) (2006) Community Forest Management as a Carbon Mitigation Option. Center for International Forestry Research, Bogor, Indonesia.

Nshubemuki, L. (1993) Forestry resources in Tanzania's wetlands: concepts and potentials. In Wetlands of Tanzania (eds G.L. Kamukala \& S.A. Crafter), pp. 37-48. IUCN, Gland, Switzerland.

Otsyina, R., Kilahama, F., Kamwenda, G. \& Nashanda, E. (2008) Status of REDD Readiness in Tanzania. Meeting of the East and Southern Africa Katoomba Group, Forest Trends, Washington, DC, USA.

Penman, J., Gytarsky, M., Hiraishi, T., Krug, T., Kruger, D., Pip at ti, R. et al. (eds) (2003a) Good Practice Guidance for Land Use, Land-Use Change and Forestry. Intergovernmental Panel on Climate Change Working Group-National Greenhouse Gas Inventories Programme, Kanagawa, Japan.

Penman, J., Gytarsky, M., Krug, T., Kruger, D., Pipatti, R., Buendia, L. et al. (eds) (2003b) Definitions and Methodological Options to Inventory Emissions from Direct Human-Induced Degradation of Forests and Devegetation of Other Vegetation Types. Intergovernmental Panel on Climate Change Working Group-National Greenhouse Gas Inventories Programme/Institute for Global Environmental Strategies, Kanagawa, Japan.

Persha, L. \& Blomley, T. (2009) Management decentralization and montane forest conditions in Tanzania. Conservation Biology, 23, 1485-1496.

REDD Tanzania Initiative (2009) Http://www.reddtz.org [accessed 27 April 2010].

Ruesch, A. \& Gib bs, H.K. (2008) New IPCC Tier 1 Global Biomass Carbon Map for the Year 2000. Oak Ridge National Laboratory, Oak Ridge, USA. Http://cdiac.ornl.gov/ [accessed 27 April 2010].

Scharlemann, J.P.W., Kapos, V., Campbell, A., Lysenko, I., Burgess, N.D., Hansen, M.C. et al. (2010) Securing tropical forest carbon: the contribution of protected areas to REDD. Oryx, 352-357.

Schmitt, C., Belokurov, A., Besançon, C., Boisrobert, L., Burgess, N.D., Campbell, A. et al. (2009) Global ecological forest classification and forest protected area gap analysis. Biological Conservation, 142, 2122-2130. 
Skutsch, M., Van Laake, P.E., Zahabu, E., Karky, B.S. \& Phartiyal, P. (2009) Community monitoring in REDD+. In Realising REDD+: National Forestry Strategy and Policy Options (eds A. Angelsen, M. Brockhaus, M. Kanninen, E. Sills, W.D. Sunderlin \& S. Wertz-Kanounnikoff), pp. 101-112. Centre for International Forestry Research, Bogor, Indonesia.

Stuart-Hill, S., Diggle, R., Munali, B., Tagg, J. \& Ward, D. (2005) The Event Book System: a community-based natural resource monitoring system from Namibia. Biodiversity and Conservation, 14, 2611-2631.

Tabor, K., Burgess, N.D., Mbilinyi, B., Kashigali, J. \& STEININGER, M.K. (2010) Forest and woodland cover and change in coastal Tanzania and Kenya, 1990 to 2000. Journal of the East African Natural History Society, in press.

Topp-Jørgensen, E., Poulsen, M.K., Lund, J.F. \& Massao, J. (2005) Community-based monitoring of natural resource use and forest quality in montane forests and miombo woodlands of Tanzania. Biodiversity and Conservation, 14, 2653-2677.

UNFCCC (UN Framework Convention on Climate Change) (2009a) Copenhagen Accord. UNFCCC, Bonn, Germany. Http://unfccc. int/resource/docs/2009/cop15/eng/lo7.pdf [accessed 27 April 2010].

UNFCCC (UN Framework Convention on Climate Change) (2009b) Cost of Implementing Methodologies and Monitoring Systems Relating to Estimates of Emissions from Deforestation and Forest Degradation, the Assessment of Carbon Stocks and Greenhouse Gas Emissions from Changes in Forest Cover, and the Enhancement of Forest Carbon Stocks. Technical Paper FCCC/TP/2009/1. UNFCCC, Bonn, Germany.

UNFCCC (UN Framework Convention on Climate Change) (2009c) Report of the Subsidiary Body for Scientific and Technological Advice on Its Thirty-First Session, Held in Copenhagen from 8 to 12 December 2009. FCCC/SBSTA/2009/8. UNFCCC, Bonn, Germany.

UN-REDD (2009) UN-REDD Programme. Http://www.UN-REDD. org [accessed 27 April 2010].

URT (United Republic of TAnZania) (1999a) Land Act of 1999. Government Printer, Dar es Salaam, Tanzania.

URT (United Republic of Tanzania) (1999b) Village Land Act of 1999. Government Printer, Dar es Salaam, Tanzania.

URT (United Republic of Tanzania) (2002) Forest Act 14 of 2002. Government Printer, Dar es Salaam, Tanzania.

URT (United Republic of Tanzania) (2009) National Framework for REDD. Vice President's Office, Dar es Salaam, Tanzania.

Van Beukering, P., Kahyarara, G., Massey, E., Di Prima, S., Hess, S. \& Geofrey, V. (2007) Optimization of the Charcoal Chain in Tanzania: A Gap Analysis. Institute for Environmental Studies, Vrije Universiteit, Amsterdam, The Netherlands.
Van der Werf, G.R., Morton, D.C., DeFries, R.S., Olivier, J.G.J., Kasibhatla, P.S., Jackson, R.B. et al. (2009) $\mathrm{CO}_{2}$ emissions from forest loss. Nature Geoscience, 2, 737-738.

Van LaAke, P.E., Skutsch, M. \& McCall, M. (2009) Data collection and national/local level. Chapter 3.4. In GOFC-GOLD: Reducing GHG Emissions from Deforestation and Degradation in Developing Countries: A Sourcebook of Methods and Procedures for Monitoring, Measuring and Reporting (eds F. Achard, S. Brown, R. DeFries, G. Grassi, M. Herold, F. Schiller et al.), pp. 1222. Report v. COP14-2. GOFC-GOLD Project Office, Natural Resources Canada, Alberta, Canada.

Verplanke, E. \& ZahaBu, E. (2009) A Field Guide for Assessing and Monitoring Reduced Forest Degradation and Carbon Sequestration by Local Communities. Kyoto: Think Global, Act Local Project report, Enschede, The Netherlands. Http://www. communitycarbonforestry.org [accessed 27 April 2010].

Wang, Y., Bonynge, G., Nugranad, J., Traber, M., Ngusaru, A., Товеу, J. et al. (2003) Remote sensing of mangrove change along the Tanzania coast. Marine Geodesy, 26, 35-48.

Wily, L.A. (2003) Community-Based Land Tenure Management: Questions and Answers about Tanzania's New Village Land Act 1999. Drylands Programme Issue Paper No. 120. International Institute for Environment and Development, London, UK. Http:// www.iied.org/pubs/display.php? $0=9295 \mathrm{IIED} \& \mathrm{n}=4 \& \mathrm{l}=9 \& \mathrm{k}=\mathrm{Wily}$ [accessed 27 April 2010].

WDPA (World Database on Protected Areas) (2009) UNEP-World Conservation Monitoring Centre and IUCN World Database on Protected Areas. Http://www.wdpa.org [accessed 27 April 2010].

Zahaвu, E., Eid, T., Kajembe, G.C., Mвwambo, L., Mongo, C., Sangeda, A.Z. et al. (2009) Forestland Tenure Systems in Tanzania: An Overview of Policy Changes in Relation to Forest Management. INA-fagrapport no. 14. University of Life Sciences, Ås, Norway.

\section{Biographical sketches}

The UN-REDD team includes staff of the Forestry and Beekeeping Division in Tanzania, of the three UN-REDD participating organizations (UNEP, UNDP and FAO) and a number of consultants and forestry experts from Tanzania and elsewhere. In collaboration they have helped Tanzania develop the basic outline of the UN-REDD National Joint Programme and have assisted work on details of how the programme (and other REDD+ projects) could be implemented and monitored at the operational scale of management: the village or area of reserved land. 